\title{
Hubungan Budaya Organisasi dan Kinerja Dosen dalam Motivasi Mahasiswa di STKIP Taman Siswa Bima
}

\author{
Adi Apriadi Adiansha ${ }^{1}$, Ibnu Khaldun Sudirman ${ }^{1}$, Asriyadin ${ }^{1, *}$ \\ ${ }^{1}$ STKIP Taman Siswa Bima \\ *asriyadin@gmail.com
}

Artikel Info

Tanggal Publikasi

$2019-12-30$

Kata Kunci

Budaya Organisasi

Kinerja Dosen

Motivasi Mahasiswa

\section{Abstrak}

Tujuan dari penelitian ini adalah untuk mendapatkan informasi hubungan antara budaya organisasi dan kinerja dosen dengan motivasi mahasiswa di STKIP Taman Siswa Bima. Pendekatan yang digunakan adalah kuantitatif dengan metode survei, Sampel dikumpulkan dari 40 dosen yang diperoleh dengan teknik acak, melalui instrumen angket yang telah divalidasi menggunakan skala likert 1-5. Kemudian data dianalisis dengan menggunakan regresi. Temuan penelitian adalah: (1) ada hubungan budaya organisasi dengan motivasi mahasiswa; (2) ada hubungan kinerja dosen dengan motivasi mahasiswa; (3) ada hubungan budaya organisasi dan kinerja dosen dengan motivasi mahasiswa. Hasil penelitian menyiratkan bahwa dalam budaya organisasi, kinerja dosen, motivasi mahasiswa.

\section{PENDAHULUAN}

Dosen adalah dosen yang memiliki kompetensi khusus di bidangnya untuk melaksanakan pengajaran, penelitian, dan pengabdian kepada masyarakat (Bali, 2013; Hamzah, Suyoto, \& Mudjihartono, 2010; Yusuf, 2014). Dosen yang memiliki kemmapuan yang baik tentu akan melahirkan hasil yang baik. Untuk mendapatkan hasil yang baik maka dosen membutukan beberapa faktor pendukung seperti budaya yang kuat, motivasi yang tinggi dan lingkungan kerja yang memadai, sehingga dengan adanya hal ini akan mengacu pada kinerja yang baik dan bernilai dalam meningkatkan pendidikan (Rino, Sulastri, \& Idris, 2013; Sihite, 2018). Kinerja Dosen adalah merupakan barometer untuk mengendalikan pendidikan yang mengarakan dalam peningkatan perguruan tinggi sebab dosen sentral utama yang memegang kunci operasional tugas dan tanggungjawab didalamnya.

Dosen adalah seseorang yang memiliki kompetensi serta memiliki kemampuan dan keunggulan berdasarkan pendidikan dan keahliannya yang diangkat oleh penyelenggara perguruan tinggi dengan tugas utama yaitu mengajar. Keberhasilan pencapaian tujuan pendidikan merupakan wujud pelaksanaan kinerja dosen. Kinerja dosen merupakan hal utama yang harus diperhatikan dalam segala proses internalisasi nilai di perguruan tinggi. Oleh karena itu, pengembangan dosen dan pengukuran kinerjanya sangatlah penting. Dosen yang kompeten untuk melaksanakan tugasnya secara profesional adalah dosen yang memiliki kompetensi pedagogik, profesional, kepribadian dan sosial yang diperlukan dalam karaktek sehingga dapat menjalankan pendidikan, penelitian, dan pengabdian terhadap masyarakat.

Kinerja dosen sangat dipengaruhi oleh budaya organisasi (Griffioen, Doppenberg, \& Oostdam, 2018; Hartono, Wahyudi, Harahap, \& Yuniawan, 2017; Köse \& Korkmaz, 2019; Tan, 2016; Toytok \& Saduman Kapusuzoglu, 2016; Winstone \& Kinchin, 2017). Budaya organisasi yang konduksif akan terbentuk tingkat kerja dosen yang lebih baik akhirnya dapat meningkatkan kinerja dosen yang efektif dan efesien, selain akan mencerminkan kinerja organsasi juga akan membentuk citra perguruan tinggi dan menunjang upaya pembangunan budaya organisasi, maka diperlukan sumberdaya manusia. Organisasi yang kuat akan memiliki ciri khas tertentu sehingga dapat memberikan energi bagi individu untuk terlibat, berfikir, bertindak dan berperilaku sesuai dengan nilai-nilai organisasi. 
STKIP Taman Siswa Bima adalah perguruan tinggi swasta dimana didalamnya terdapat kecenderungan sehingga dapat menurunkan nilai serta lambatnya perkembangan pendidikan yang ada di STKIP Taman Siswa Bima, hal ini ditandai dengan budaya yang dibentuk tidak sesuai dengan kondisi yang ada, sehingga akan berpengaruh terhadap kinerja. Namun demikian, kenyataan yang terjadi di STKIP Taman Siswa Bima, perguruan tinggi dijadikan sebagai target pasar bagi pengelola lembaga institusi yang akan melahirkan kepentingan bagi oknum-oknum yang ada didalamnya, sehingga orentasinya hanya kepada pemenuhan kebutuhannya dan tidak lagi memperhatikan kualitas perguruan tinggi dan prestasi pendidikan serta mahasiswa yang ada didalamnya. Maka lahirlah budaya yang tidak baik, serta terjadilah permasalahan-permasahan yang dilakukan oleh mahasiswa, seperti aksi, penyegelan kampus serta konflik internal.

Hal ini ditandai dengan budaya yang memang tidak dibentuk dengan baik karna kualitas pendidikan dan prestasi mahasiswa (Susilawati \& Adiansha, 2018) tidak diutamakan dalam perguruan tinggi. Dengan adanya masalah tersebut akan berpengaruh terhadap masyarakat terutama yang berhubungan dengan budaya organisasi yang belum dapat diterapkan sepenuhnya oleh lembaga sehingga hal ini akan berpengaruh terhadap perkembanga perguruan tinggi. Masalah yang dihadapi oleh lembaga pendidikan di STKIP Taman Siswa Bima, tidak terlepas pada budaya organisasi, motivasi dan lingkungan kerja sehingga akan berdampak pada kinerja dosen yang diantaranya (1) Kurangnya sumberdaya manusia yang profesional (2) Penerapan sistem organisasi yang tidak tepat dengan kondisi lingkungan STKIP Taman Siswa Bima dan (3) Pemenuhan sarana dan prasarana yang belum optimal.

Berdasarkan uraian di atas dapat dikemukakan perumusan masalah sebagai berikut: 1) Apakah terdapat hubungan antara budaya organisasi dengan motivasi mahasiswa? 2) Apakah terdapat hubungan antara kinerja Dosen dengan motivasi mahasiswa? 3) Apakah terdapat hubungan antara budaya organisasi dan kenerja dosen dengan motivasi mahasiswa?

\section{METODE PENELITIAN}

Penelitian ini bertujuan untuk untuk a) mengetahui hubungan antara budaya organisasi STKIP Taman Siswa Bima dengan kinerja dosen, b) mengetahui hubungan antara kenerja Dosen dengan motivasi mahasiswa, c) mengetahui hubungan anara budaya organisasi dan kinerja dosen dengan motivasi mahasiswa. Penelitian ini dilaksanakan di STKIP Taman Siswa Bima, Jln Pendidikan Taman Siswa No.1 Palibelo-Bima-NTB. Sedangkan metode yang digunakan dalam penelitian ini adalah metode survey pendekatan kuantitatif. Populasi dalam penelitian ini adalah dosen-dosen yang ada di STKIP Taman Siswa Bima, dan sampel dari penelitian ini sebanyak 40 orang. Waktu pelaksanaan penelitian dilaksanakan pada semester Ganjil tahun akademik 2019/2020.

\section{HASIL DAN PEMBAHASAN}

Hasil pengujian normalitas galat taksiran regresi $\mathrm{Y}$ atas $\mathrm{X}_{1}$ dengan liliefors menunjukkan bahwa sebaran data penelitian berasal dari populasi berdistribusi normal, dengan $\mathrm{L}_{\mathrm{o}(0,121)}<\mathrm{L}_{\text {tabel }(0,140)}$, sedangkan Hasil pengujian normalitas galat taksiran regresi $\mathrm{Y}$ atas $\mathrm{X}_{2}$ dengan liliefors menunjukkan bahwa sebaran data penelitian berasal dari populasi berdistribusi normal, dengan $\mathrm{L}_{\mathrm{o}(0,129)}<\mathrm{L}_{\text {tabel }(0,140)}$.

Hasil pengujian Homogenitas Varians $\mathrm{Y}_{\text {atas }} \mathrm{X}_{1}$ dengan uji bartlett menunjukkan bahwa sebaran

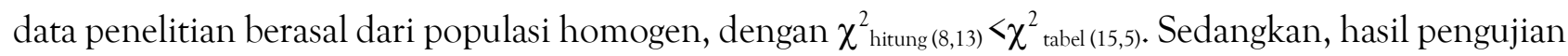
Homogenitas Varians $\mathrm{Y}$ atas $\mathrm{X}_{2}$ dengan uji bartlett menunjukkan bahwa sebaran data penelitian berasal dari populasi homogen, dengan $\chi_{\text {hitung (1,92) }}^{2} \chi^{2}$ tabel(11,1). 
Hasil penelitian menemukan bahwa: pertama, terdapat hubungan positif yang berarti antara budaya sekolah dengan motivasi mahasiswa yang diperoleh koefisien korelasi 0,609, koefisien determinasi $37,09 \%$, $t_{\text {hitung }}(4,73)>t_{\text {tabel }}(1,70)$, dan persamaan regresi $\hat{Y}=45,11+0,516 X_{1}$.

Hasil analisis korelasi sederhana antara budaya organisasi dengan motivasi mahasiswa diperoleh nilai koefisien korelasi ry 1 sebesar 0,609. Nilai ini memberikan pengertian bahwa keterkaitan antara budaya organisasi dengan motivasi mahasiswa adalah signifikan atau positif, artinya makin tinggi tingkat budaya organisasi akan diikuti dengan naiknya motivasi mahasiswa tersebut.

Kedua, terdapat hubungan positif yang berarti antara kinerja dosen dengan motivasi mahasiswa yang diperoleh koefisien korelasi 0,476 , koefisien determinasi $22,66 \%$, $t_{\text {hitung }}(3,34)>t_{\text {tabel }}(1,70)$, dan persamaan regresi $\hat{\mathrm{Y}}=57,98+0,422 \mathrm{X}_{2}$.

Hasil analisis korelasi sederhana antara kinerja dosen dengan motivasi mahasiswa diperoleh nilai koefisien korelasi $r_{\mathrm{y} 2}$ sebesar 0,476. Nilai ini memberikan pengertian bahwa keterkaitan antara kinerja dosen dengan motivasi mahasiswa adalah signifikan atau positif, artinya makin tinggi tingkat kinerja dosen akan diikuti dengan naiknya motivasi mahasiswa tersebut.

Besarnya sumbangan atau kontribusi variabel kinerja dosen terhadap motivasi mahasiswa dapat diketahui dengan cara mengkuadratkan perolehan nilai koefisien korelasi sederhananya. Hasil pengkuadratkan nilai koefisien korelasi sederhananya adalah sebesar 0,2266. Secara statistik nilai ini memberikan pengertian bahwa kurang lebih 22,66 persen variasi Kinerja dosen ditentukan atau dijelaskan oleh motivasi mahasiswa dengan pola hubungan fungsionalnya seperti ditunjukan oleh persamaan regresi tersebut di atas.

Ketiga, terdapat hubungan positif yang berarti antara budaya sekolah dan kinerja dosen dengan motivasi mahasiswa, koefisien korelasinya 0,674, koefisien determinasi 45,40\%, $F_{\text {hitung }}(15,40)>F_{\text {tabel }}$ $(5,25)$, dan persamaan regresi $\hat{Y}=27,91+0,429 X_{1}+0,272 X_{2}$.

Hasil analisis korelasi ganda antara budaya organisasi dan kinerja dosen dengan motivasi mahasiswa diperoleh nilai koefisien korelasi ganda sebesar $R_{y 12}$ sebesar 0,674 . Nilai ini menunjukan bahwa keterkaitan antara budaya organisasi dan kinerja dosen dengan motivasi mahasiswa baik. Dengan demikian berarti makin naiknya budaya organisasi dan kinerja dosen, maka diikuti dengan tingginya motivasi mahasiswa.

Besarnya sumbangan atau konstribusi variabel budaya organisasi dan kinerja dosen terhadap motivasi mahasiswa bersama-sama dapat diketahui melalui nilai koefisien determinasi $\mathrm{R}_{\mathrm{y} 12}^{2}$ sebesar 0,454. Hasil analisis tersebut menunjukan bahwa lebih kurang 45 persen variasi motivasi mahasiswa ditentukan atau dijelaskan oleh budaya organisasi dan kinerja dosen secara bersama-sama, seperti ditentukan oleh persamaan regresi tersebut di atas.

\section{KESIMPULAN}

Kesimpulan dalam penelitian ini adalah Pertama, terdapat hubungan positif antara budaya organisasi dengan motivasi mahasiswa. Kekuatan hubungannya ditunjukkan oleh koefisien korelasi 0,609 dan koefisien determinasi 0,3709 yang artinya 37,09\% variasi motivasi mahasiswa, dapat dijelaskan oleh variasi budaya organisasi sekolah. Dengan kata lain, makin kuat budaya organisasi maka makin tinggi motivasi mahasiswa. Kedua, terdapat hubungan positif antara kinerja dosen dengan 
motivasi mahasiswa. Kekuatan hubungannya ditunjukkan oleh koefisien korelasi 0,476 dan koefisien determinasi 0,2266 yang artinya $22,66 \%$ variasi motivasi mahasiswa, dapat dijelaskan oleh variasi kinerja dosen. Dengan kata lain, maka semakin tinggi kinerja dosen maka makin tinggi motivasi mahasiswa. Ketiga, terdapat hubungan positif antara budaya organisasi dan kinerja dosen dengan motivasi mahasiswa. Kekuatan hubungannya ditunjukkan oleh koefisien korelasi ganda 0,674 dan koefisien determinasi 0,454 yang artinya 45,40\% variasi motivasi mahasiswa dapat dijelaskan oleh variasi budaya organisasi dan kinerja dosen. Dengan kata lain dapat dikemukakan makin kuat budaya organisasi dan kinerja dosen maka makin tinggi pula motivasi mahasiswa.

\section{Daftar Pustaka}

Bali, M. M. (2013). Peran Dosen dalam Mengembangkan Karakter Mahasiswa. Humaniora, 4(2), 800. https://doi.org/10.21512/humaniora.v4i2.3508

Griffioen, D. M. E., Doppenberg, J. J., \& Oostdam, R. J. (2018). Organisational influence on lecturers' perceptions and behaviour towards change in education. Studies in Higher Education, 43(11), 18101822. https://doi.org/10.1080/03075079.2017.1284191

Hamzah, Suyoto, \& Mudjihartono, P. (2010). Sistem Pendukung Keputusan Penilaian Kinerja Dosen Dengan Metode Balanced Scorecard ( Studi Kasus: Universitas Respati Yogyakarta ). Seminar Nasional Informatika 2010 (SemnasIF), 2010, 82-90.

Hartono, E., Wahyudi, S., Harahap, P., \& Yuniawan, A. (2017). Does Organizational Learning Affect the Performance of Higher Education Lecturers in Indonesia? The Mediating Role of Teaching Competence. International Journal of Environmental and Science Education, 12(4), 865-878.

Köse, M. F., \& Korkmaz, M. (2019). Why are some universities better? An evaluation in terms of organizational culture and academic performance. Higher Education Research $\mathcal{E}$ Development, 38(6), 1213-1226. https://doi.org/10.1080/07294360.2019.1634679

Rino, Sulastri, \& Idris. (2013). Pengaruh Teknologi Informasi Smart Kampus, Implementasi Sistem Manajemen Mutu Iso 9001:2008 Dan Skil Kepemimpinan Terhadap Knowledge Management, Motivasi Kerja Dan Kinerja Dosenuniversitas Negeri Padang Rino, Sulastri, Idris. Jurnal Riset Manajemen Bisnis Dan Publik, 1(1).

Sihite, M. (2018). Marketing Perguruan Tinggi Meningkatkan Daya Saing : Suatu Tinjauan Konseptual. Seminar Nasional Sains EZ Teknologi Informasi (SENSASI) 2018, 7(2007), 33-44.

Susilawati, Y., \& Adiansha, A. A. (2018). Hubungan Kepribadian dan Efikasi Diri Dengan Motivasi Belajar Siswa Kelas IV Sekolah Dasar. 8(2), 142-151.

Tan, C. N.-L. (2016). Enhancing knowledge sharing and research collaboration among academics: the role of knowledge management. Higher Education, 71(4), 525-556. https://doi.org/10.1007/s10734-015-9922-6

Toytok, E. H., \& Saduman Kapusuzoglu. (2016). Influence of School Managers' Ethical Leadership Behaviors on Organizational Culture: Teachers' Perceptions. Eurasian Journal of Educational Research, (66), 373-388.

Winstone, N. E., \& Kinchin, I. M. (2017). Literacy as an antidote to pedagogic frailty. Psychology Teaching Review, 23(1), 15-29.

Yusuf, J. (2014). Kompetensi Dosen-Dosen Bahasa Arab Di IAIN Raden Intan Lampung. Jurnal Al Bayan UIN Raden Intan, 6(2). 